\title{
Collective action and government: still a mystery*
}

\section{Philip Keefer}

\section{Introduction}

The success of a society is the ultimate public good: individually, members of society can make themselves better off by enjoying the fruits of success without contributing to the preconditions for it. Success is therefore a puzzle, one that has been the focus of some of the most notable scholarship in the social sciences. Douglass North asked how some societies manage to suppress individual incentives to predate on the efforts of others, one precondition for societal success. Mancur Olson probed the conditions under which groups can persuade individual members to make sacrifices for the collective good, another precondition. Elinor Ostrom brought the question down to the level of communities, where even frequent opportunities for personal contact are not always sufficient to prevent the degradation of common resources.

Nevertheless, despite profound contributions arising from more than 50 years of research, we still only partially understand why societies exhibit significant differences, among themselves and over time, in how they resolve the dilemmas of collective action. The future agenda of research in institutional economics is therefore very much like the past agenda: how and when do societies resolve these dilemmas? What are the consequences if they do not? How can public policy promote them or are collective action equilibria always unstable, carrying the seeds of their own destruction?

These questions constitute an intimidating research agenda. This chapter's slightly more modest ambition is to pose these questions in the specific context of government policy making. Under what conditions do citizens succeed in overcoming the collective action problem of holding governments accountable for social progress? Under what conditions do these arrangements break down, particularly given the incentives of political competitors to undermine their opponents' capacity for collective action? And under what conditions do governments grant public sector organizations the authority to resolve their internal collective action problems? The

\footnotetext{
* The findings, interpretations, and conclusions expressed in this chapter are entirely those of the author and do not necessarily represent the views of the Inter-American Development Bank, its Board of Directors, nor the countries that they represent.
} 
discussion that follows expands on these questions and suggests specific hypotheses that scholars might usefully investigate to address them.

\section{Solving problems of collective action: social norms}

At least since Olson's Logic of Collective Action (1965) scholars have focused on four preconditions of collective action: homogeneity of interests; clarity about the distribution of the costs and benefits of collective action; limits on the extent to which individuals free ride on the efforts of others; and sufficient communication among members to allow for coordinated action. However, although these determinants are well understood, we still lack definitive tests of the central hypotheses that emerge from them. For example, do societies in which citizens have similar preferences and exhibit strong cooperative norms exhibit public policies that correspond more closely to citizen preferences? Even more basically, if norms of cooperation are insufficient to overcome free-rider problems, organizations that address information, free-rider, and coordination problems are more likely to matter. Does the presence of such organizations, particularly in the case of political parties, lead to public policies that correspond more closely to citizen preferences?

Notable research on the effects of heterogeneity in citizens' preferences on public policy has focused on ethnic heterogeneity: more ethnically heterogeneous jurisdictions seem to provide fewer public goods (Alesina, Baqir and Easterley, 1999). In general, however, there is still insufficient research on the hypothesis that the greater is the heterogeneity of policy preferences in a society, the less efficient are the public policies that governments pursue and the fewer are the public goods that they provide.

Opacity in the distribution of the costs and benefits from collective action is another potential source of differences in collective action across countries. Although societies grapple with decisions in similar policy domains - redistribution, infrastructure, education, defense, environment - they differ in the degree to which members are informed about the costs and benefits of policy options. A large literature on information and development suggests that this type of opacity might matter, but the evidence so far suggests that the effects on collective action are weak. Keefer and Khemani (2015), for example, show that families in Benin that are more informed about education's benefits make the private decision to invest more in their children's education. However, the schools that their children attend are no better than schools where parents are less well informed. A leading - so far untested - explanation for this is that parents, though informed, confront additional, binding challenges to collective action.

Most research on collective action has focused on free riding. In the context of government policy, the central free-riding problem is that citizens who value a public policy have an incentive to free ride on the efforts of like-minded citizens to persuade government to adopt the policy. Informal or social norms can mitigate 
the free-riding problem if they shift individual attitudes along three dimensions. Do norms lead individuals to believe that other people can be trusted (e.g., to participate in collective action when they say they will)? Do they intrinsically motivate individuals to cooperate with one another? And do they intrinsically motivate individuals to exert effort to punish those who are not cooperative? Ample evidence indicates that these vary significantly across societies. For example, the average country responses to the World Values Survey exhibit substantial variation in whether respondents agree that "most people can in general be trusted," and these averages are significantly associated with differences in per capita incomes (Knack and Keefer, 1997). Even in the most cooperative societies, though, they fall short of fully resolving collective action dilemmas.

A large experimental literature on public good games also documents that individuals have intrinsic incentives to cooperate, but they cooperate at less than optimal levels and cooperation often deteriorates over time. In these games, individuals receive an endowment and are asked to contribute some fraction of it to a common pool of funds. The value of this common pool - the public good - is equal to two or three times the total contributions of the players. At the end of play, the public good is divided evenly among the players and players exit the game with their share of the public good plus the amount of their original endowment that they did not contribute. Individually, players therefore have a strong incentive to free ride; collectively, they are better off contributing their entire endowment. In fact, in the large literature that has examined this game, researchers have found that players contribute only about half of their endowment, with contributions sometimes going to zero in repeated iterations (Levitt and List, 2007).

In other experiments, subjects will sometimes punish non-cooperative behavior, even though this is costly to them and others receive most of the benefits. Again, societies differ significantly with respect to individuals' willingness to exert costly effort to impose sanctions on free riders. However, those differences can be surprising and argue against relying on social norms to support collective action. Herrmann, Thöni and Gächter (2008) conduct laboratory experiments in 16 different parts of the world. Not only do rates of punishment imposed on low contributors vary widely across societies, but the high contributors - those who act most cooperatively - are sometimes also punished.

Norms of cooperation are higher when societies exhibit other features that promote collective action. Herrmann et al. (2008) find that norms of cooperation and punishment are correlated. Knack and Keefer (1997) show that expressions of trust in others are greater in countries in which institutions restrain predatory actions by chief executives. Herrmann et al. (2008) also observe that antisocial punishments are more common in societies where standard cross-country measures of the rule of law are low.

Although research on the intrinsic motivation of individuals to avoid free riding is vast, at least two important questions remain open. First, do intrinsic differences in 
social norms - to cooperate and to punish uncooperative behavior - account for actual differences in real-world collective action to influence government policy? Second, where do these norms come from? To the extent that they seem to be correlated with the formal institutional environment (checks and balances in Knack and Keefer and rule of law in Herrmann et al.), it is possible that they are the outcomes, rather than determinants, of citizen success in undertaking collective action. A growing body of research that exploits natural experiments in history adds some support to this conjecture (e.g., Nunn and Wantchekon, 2011).

The fourth condition for collective action, coordination among members of the collective, has also received significant attention in the literature. Social norms play a small role, both in theory and in the empirical literature, as potential solutions to coordination difficulties. Instead, attention has focused more on the effects of government policy (e.g., freedom of assembly) and technology (e.g., social media) on coordination, and on specific types of collective action, such as demonstrations. This is reasonable: problems of coordination are perhaps less a function of human behavior than of the technological and policy determinants of the costs of citizen communication. The interaction of technology and policy points to two important and untested hypotheses. One is that cross-country variations in collective action that result from coordination difficulties are the product of active government efforts to prevent coordination (censorship, monitoring and blocking social media, etc.). Another is that if governments can prevent citizen coordination, citizens are essentially powerless to influence government policy. In this case, citizen interests are restored as a government priority only if sympathetic elites within government, who can coordinate (since they are elites), advocate their interests.

\section{Solving problems of collective action: organizations and political parties}

If groups cannot count on social norms to resolve problems of collective action, and if individuals with homogeneous preferences do not spontaneously identify and coordinate with each other, they must organize. This is not a tautology that is, to solve a problem of collective action one must act collectively. Instead, it implies delegating the recruitment, monitoring and allocation of rewards and punishments to some members (e.g., organization leaders), and implanting rules that allow members to control leaders who shirk on these tasks. The difficulty of forming organizations, and the likelihood that those difficulties vary across societies, constitutes the most promising focus of research on the relationship between collective action and public policy. ${ }^{1}$

Many types of citizen organizations solve collective action problems related to the pursuit of political goals. Political parties are the most salient and vary dramatically

1 This is consistent with the important role that organizations play in the analysis of North, Wallis and Weingast (2009). 
across countries. They may be organized around charismatic individuals, function as party machines, consist of an assembly of patrons and their clients, or be composed of individuals with like-minded preferences regarding the conduct of public policy. Some are long-lived, surviving the departure of their founder, others evanescent. The sources of this variation, and its effects, are not well understood (Keefer, 2018).

Each party modality confronts its own collective action dilemma. Programmatic parties attempt to gain electoral advantage by solving the collective action problems of citizens who would like government to adopt specific policies, for example regarding government intervention in the economy, redistribution, or restrictions on trade. All citizens with similar policy preferences are better off if they vote for candidates who share those preferences. However, each has an incentive to free ride on the votes of others by allowing others to vote for the party while they stay at home rather than take the trouble to vote, or sell their vote to a candidate who has no interest in policy.

In contrast, clientelist parties make electoral appeals based on transfers to voters, either before the election (vote buying) or after (promising transfers after the election) to gain support. Since these parties are not organized around broad public policies, they do not solve the collective action problems of citizens with similar policy preferences. Instead, they address the collective action challenge of extracting government resources for private benefit. To prevent free riding, these parties must be sufficiently organized to deny transfers to citizens who do not support the party and reward those who do.

Both types of parties can attenuate free-riding problems by investing in "get-outthe-vote" efforts; using media to promote a norm among members of supporting the party and resisting inducements to free ride; and rewarding supporters with candidacies. In the case of programmatic parties, success in this endeavor depends on whether citizens believe that its candidates will carry out the program, which in turn is a function of the party's organization: does it make reneging on its program difficult by recruiting members based on their preferences for the program and punishing members who shirk in supporting the program?

The dramatic differences in the policy consequences of these two types of parties give rise to important research questions. Why do programmatic parties, aimed at solving the collective action problems of citizens with similar policy preferences, thrive in some countries and not others? Under what conditions can programmatic parties emerge in competition with clientelist parties if clientelist parties make vote-buying offers to their voters to free ride and not vote for the programmatic party?

One of the interesting and under-researched hypotheses that emerges from these questions is that programmatic parties are more likely to emerge when voters with similar policy preferences exhibit pre-existing social or other ties that lower the 
costs to parties of solving their collective action problems. The connection between unions and left-wing parties in the political history of Europe and the United States is widely noted in the literature. However, the possibility that unions might have facilitated the emergence of left-wing parties by solving their free-rider problem has received less attention.

A large literature links social capital to development outcomes. ${ }^{2}$ An unexplored mechanism linking the two is that when social capital is limited, as in the Putnam, Leonardi and Nanetti (1993) sense that networks among citizens are thin and fail to build social norms of reciprocity, programmatic parties are more difficult to construct. This is especially intriguing because, in principle, the sporting or music clubs that drive the formation of reciprocity in Putnam et al.'s research have nothing to do with politics or policy. They recruit members according to their athletic and musical skills and interests and members need not share common interests regarding government policy. How, then, does the fact that individuals are active in sporting or music clubs facilitate their ability to demand public goods from government? How does it allow them to better restrain corrupt behavior by officials?

One possibility is that club membership increases the value members place on others' preferences, reducing conflict while solving coordination problems. Another is that, in fact, social groups do consist of like-minded individuals, facilitating the transition from socially oriented to politically oriented group activity. There is, though, little evidence on these or other potential explanations of the development impact of social organization.

Another significant and still-unresolved issue in our understanding of institutions and political economy is the conditions under which parties, especially programmatic parties, survive. In Italy and Brazil, long-standing parties with programmatic characteristics collapsed followed the aggressive actions of prosecutors to pursue political corruption. In Venezuela, the two dominant parties, less clearly programmatic, imploded after generations of sharing power and the spoils of office. The major parties of France experienced dramatic drops in electoral support.

To begin to understand party demise, an initial hypothesis is that programmatic parties should be longer-lived than clientelist parties. If the only tie that binds citizens to a party is the promise of a transfer, then any political competitor capable of making such a promise can persuade supporters of one party to switch to another. Moreover, if the credibility of these promises rests on the personal relationship of citizens with specific politicians, then the costs to these politicians of switching parties, or starting their own, are low. In contrast, supporters of a programmatic party cannot costlessly abandon the party unless another party exists that similarly reflects their preferences. Politicians in a programmatic party equally confront costs of leaving: their electoral support is a function not only of their personal

2 An example, though with a particularly negative twist, is the account by Satyanath, Voigtländer and Voth (2017) of support for the Nazi Party. 
characteristics, which they can take with them, but also of their party's brand, which they cannot.

Programmatic parties might also founder when voter sentiment shifts. For example, voter beliefs about which policies are needed to achieve their objectives may change, moving away from the policies advocated by programmatic parties. An essential element of these parties is to recruit candidates who support their policies, rewarding legislators who advance them, and creating a party brand that is associated with them. These same organizational characteristics make it difficult to accommodate shifts in voter preferences away from these policies.

Finally, just as programmatic parties are more difficult to establish in clientelist environments, in these same environments a plausible conjecture is that they are also more vulnerable to failure. Clientelist parties make pre-electoral transfers to voters (buying their votes) and promise them post-electoral transfers, all at the expense of broader policy goals and the provision of public goods (Keefer and Vlaicu, 2017). The existence of clientelist parties prepared to buy votes makes free riding by members of programmatic parties more likely. These parties can respond by engaging in these practices themselves. This, however, jeopardizes their ability to pursue their programmatic goals and exposes them, as in Brazil and Italy, to accusations of corruption and to prosecution. These damage their brand name and repel their voters. Programmatic parties are less likely to endure and are more likely to tolerate corrupt behavior by their members when they compete against purely clientelist parties. At the same time, when programmatic parties take control of government, they are more likely to pass and enforce laws that make clientelist forms of campaigning, particularly vote buying, illegal.

\section{Sustaining collective action in the presence of political competition}

Exactly because collective action plays such a large role in the political process, opponents target each other's capacity to undertake collective action to gain political advantage. We have no systematic understanding of these efforts, however, although some manifestations of the phenomenon are notorious and well researched. For example, the earlier discussion of government policies to limit coordination concerns precisely this phenomenon.

Even democratic governments pursue policies that undermine their opponents' ability to organize support. In the United States, Republicans make it more difficult and Democrats easier for workers to act collectively, while Democrats place limits on individual contributions and Republicans relax them by changing the rules governing the contributions that single (rich) contributors can make to political campaigns. Governments outlaw some or all political parties, requiring candidates to run as individuals. In non-democracies, autocrats invest heavily in security services that exist to undermine collective action by regime opponents. However, in doing 
this they must strike an uneasy balance. Greater cooperation within and across security forces - that is, greater capacity for collective action by security forces makes them more efficient in suppressing organized dissent, but also makes them better able to mount coups against the autocrat. Under some conditions, governments manipulate information and communication - and therefore coordination among citizens, especially opponents (e.g., Gehlbach and Sonin, 2014).

In fully democratic settings, the political rewards of undermining collective action by opponents are set against the political costs of abridging principles such as freedom of assembly and free speech. To the extent that these principles are widely valued, the costs of limiting collective action may exceed the benefits. The legislative success of Republican efforts to restrict the organization of workers and Democratic efforts to restrict campaign donations has varied significantly over time. That variation could be due to the changing fraction of Republican and Democratic voters who value not only partisan success, but also the freedom of assembly of all citizens, including workers, and of speech, including speech funded by millionaires. In contrast, since vote buying does not have the same normative value as freedom of assembly, laws to restrict vote buying to disadvantage political opponents are more likely to succeed.

This argument suggests that the more ingrained are norms of fairness regarding access to collective action, and the more capable are citizens of acting collectively to defend these norms, the less likely are parties to exploit their control of government to undermine their opponents' capacity to act collectively. Unfortunately, this implies a virtuous - or vicious - cycle, since norms of fairness are more likely to emerge among people who have already experienced the benefits of unfettered collective action. Consistent with this, many desirable development outcomes, including curbs on predatory behavior by government, are associated with the age of a democracy. Experience with collective action may be associated with social norms that reject efforts to curb it.

\section{Collective action and state capacity}

One significant strand of research is preoccupied with the conditions under which politicians have appropriate incentives regarding the provision of public goods. Another strand recognizes that these incentives depend on the ability of governments to translate politicians' wishes into actual policy. This ability is captured by the somewhat cloudy concept of state capacity. Voters have no reason to value politician promises if they believe that the state apparatus cannot deliver on them. At the same time, though, politicians can improve state capacity. Why do they choose to do so in some places and not others? We still have far from a complete picture of the conditions under which politicians strengthen state capacity (grant autonomy to agencies, allow agencies to organize themselves to ensure the pursuit of a collective goal), or do so in some sectors and not others. Typically, debate centers on the time horizon of politicians: the longer it is, the more likely they are to 
embark on the project of improving state capacity. However, the presumption that state capacity takes years to improve does not always hold: politicians can quickly remove restrictions on organizations related to recruitment, compensation, evaluation, as well as on cross-unit coordination and agency discretion, and can impose limits on their own individual interventions in organization affairs.

One key aspect of state capacity is the ability to collect taxes. Important recent analyses focus on this dimension of capacity and emphasize the importance of fiscal constraints as a limiting factor in building it (e.g., Besley and Persson, 2010; Dincecco and Katz, 2014). However, in practice fiscal obstacles to tax collection may not be significant: the 2015 budget of the US Internal Revenue Service was $\$ 11.5$ billion, barely a footnote in a total federal government budget of $\$ 3.35$ trillion. If these modest fiscal costs of collecting taxes were the only obstacle to state capacity, small shocks might be sufficient to tip countries towards strengthening capacity. Instead, however, a substantial literature argues that war plays a key role; Gennaioli and Voth (2015) specifically link war to the development of tax capacity.

Other research emphasizes the challenges posed by the organizational, rather than fiscal, demands of state capacity: the public administration must be able to recruit and promote meritocratically, create and exchange information, and plan, all towards the transparent goal of improving citizen welfare through revenue-raising, public good provision and regulation. Such a public administration presents a challenge to politicians, however. Civil servants who are recruited on merit, operate collectively, share information, and are bound together by an ethic of public service are less susceptible to political influence. A well-organized public administration therefore reduces politician discretion and authority over public policy. The costs that this creates for politicians range from the modest - preventing them from asking for special treatment for themselves or their constituents - to the dramatic: a well-organized public administration can challenge politicians by investigating allegations of corruption or other illegal acts, or by obstructing the implementation of politicians' key initiatives.

When do politicians accept a well-organized public administration, despite the challenges it can pose to them? One line of research emphasizes the importance of citizen collective action and programmatic political parties (Cruz and Keefer, 2015). Programmatic political parties solve the collective action problems of like-minded citizens, allowing them to punish politicians who fail to pursue their preferred program. To the extent that the program requires a capable public administration, programmatic politicians are more likely to improve state capacity. They find that countries with more programmatic parties were more likely to accept World Bank loans to reform public administration.

Another hypothesis, not explicitly tested in the literature, is that politicians improve state capacity when an organization's mission corresponds with their own. When politicians confront public organizations with missions antithetical to their policy 
preferences, they prefer to undermine state capacity. This means that when polarized parties alternate in power, state capacity should steadily decline.

Finally, if state capacity is in fact difficult to improve, then voters should rationally not hold politicians accountable for complicated public services, such as education. Instead, they should judge them on benefits that are easy to provide, such as jobs or cash transfers. This points to another unfavorable feedback loop: where state capacity is low, politicians have no incentive to fix it, because voters do not hold them accountable for the services that are dependent on state capacity. However, where it is high, politicians will be leery of undermining state capacity to deliver the services that voters expect from them.

\section{Conclusion}

Intrinsic motivation can solve problems of collective action - but it is also fundamental to a successful research agenda. Without it, both the conduct and output of research are dreary. The foregoing areas of research are guaranteed only to provide intrinsic motivation to one researcher, the author; hopefully, they intrinsically motivate others. Moreover, just as reducing information asymmetries attenuates problems of collection action, data availability is fundamental to a successful research agenda. Unfortunately, one reason that the collective action agenda has significant unanswered questions is that data gaps are legion. Still, the foregoing offers a plausible set of criteria for prioritizing where we should look for data. In sum, if nothing else, the observations in this chapter constitute a set of worthy goals, any of which, if achieved, would constitute a significant step forward in our understanding of economic development and why some societies succeed when others do not.

\section{References}

Alesina, A., R. Baqir and W. Easterly (1999). "Public goods and ethnic divisions.” The Quarterly Journal of Economics, 114(4), 1243-84.

Besley, T. and T. Persson (2010). "State capacity, conflict, and development." Econometrica, 78(1), 1-34.

Cruz, C. and P. Keefer (2015). "Political parties, clientelism, and bureaucratic reform." Comparative Political Studies, 48(14), 1942-73.

Dincecco, M. and G. Katz (2014). "State capacity and long-run economic performance." The Economic Journal, 126(590), 189-218.

Gehlbach, S. and K. Sonin (2014). "Government control of the media." Journal of Public Economics, 118, 163-71.

Gennaioli, N. and H.-J. Voth (2015). "State capacity and military conflict." Review of Economic Studies, $82(4), 1409-48$.

Herrmann, B., C. Thöni and S. Gächter (2008). “Antisocial punishment across societies." Science, 319(5868), $1362-7$.

Keefer, P. (2018). "Organizing for prosperity: Collective action, political parties and the political economy of development." In C. Lancaster and N. van de Walle (eds), Oxford Handbook of Politics of Development. Oxford: Oxford University Press, pp. 431-57. 
Keefer, P. and S. Khemani (2015). "Mass media and public education: The effects of access to community radio in Benin." Journal of Development Economics, 109 (C), 57-72.

Keefer, P. and R. Vlaicu (2017). "Vote buying and campaign promises." Journal of Comparative Politics, 45(4), 773-92.

Knack, S. and P. Keefer (1997). "Does social capital have an economic payoff? A cross-country investigation." The Quarterly Journal of Economics, 112(4), 1251-88.

Levitt, S.D. and J.A. List (2007). "What do laboratory experiments measuring social preferences reveal about the real world?" Journal of Economic Perspectives, 21(2), 153-74.

North, D.C., J.J. Wallis and B.R. Weingast (2009). Violence and Social Orders: A Conceptual Framework for Interpreting Recorded Human History. New York: Cambridge University Press.

Nunn, N. and L. Wantchekon (2011). "The slave trade and the origins of mistrust in Africa." The American Economic Review, 101(7), 3221-52.

Olson, M. (1965). The Logic of Collective Action: Public Goods and the Theory of Groups. Cambridge, MA: Harvard University Press.

Putnam, R., R. Leonardi and R.Y. Nanetti (1993). Making Democracy Work: Civic Traditions in Modern Italy. Princeton, NJ: Princeton University Press.

Satyanath, S., N. Voigtländer and H.-J. Voth (2017). "Bowling for fascism: Social capital and the rise of the Nazi Party." Journal of Political Economy, 125(2), 478-526. 